\title{
Where Do Profits and Jobs Come From? Employment and Distribution in the US Economy
}

\author{
Lance Taylor and Özlem Ömer*
}

\author{
Working Paper No. 72
}

\section{April 8, 2018}

\begin{abstract}
"Meso" level analysis of 16 producing sectors sheds light on broad forces shaping growth of employment and profits. In a growth decomposition from 1990 through 2016, employment responds positively to output increases and negatively to rising productivity. The macro profit share responds positively to sectoral productivity and demand shifts, and negatively to real wage increases. The decomposition weights suggest that wage repression raises profits in business services, education and health, wholesale and retail trade, and parts of manufacturing. Observed profit growth was robust in manufacturing, trade, finance and insurance, and information. The latter two (and wholesale trade) benefitted from favorable demand shifts. However, they generate less than a quarter of total profits. Owners of real estate receive more than a quarter but their share is not increasing. Growth of the remaining one-half of profits has been due to demand shifts and productivity growth which exceeded real wage increases. Market power matters in all sectors. The strongest effects may act against employment and real wages in labor markets.
\end{abstract}

* New School for Social Research. Support by the Institute for New Economic Thinking (INET) and comments by Thomas Ferguson, Frank Lysy, Duncan Foley, and Codrina Rada are gratefully acknowledged. 
Keywords: income distribution, wealth, monopoly power, rents, low wages

JEL Codes: D31, D33, E2, E12, E24, J40, L11 
Income distribution and employment are crucial macroeconomic indicators. Profits are key to distribution. The profit share has risen steadily since around 1980. Households near the top of the size distribution of income receive business profits through various channels including interest, dividends, capital gains, proprietors' incomes, share buybacks, and even labor compensation which in the data includes profit-related items such as bonuses and stock options. Rising household inequality can be traced directly to increasing profits fed by slower growth of real wages than of productivity (Taylor, 2018).

The ratio of employment to the working age population fluctuates around $60 \%$. It reached a post-WWII high of $64 \%$ in 1990 at the peak of a business cycle, dropped to 55\% in the wake of the Great Recession, and is now nearing 62\% (see Figure 3a below). Rising income inequality and oscillating employment are not the happiest macroeconomic combination. Causes are explored in this paper, with an emphasis on changing structural relationships among major sectors of the US economy.

\section{Output, productivity, and employment}

Luigi Pasinetti (1981) pointed out long ago that at both the sectoral and macroeconomic levels, the ratio of employment to (working age) population rises if growth in output per capita exceeds increases in labor productivity, conventionally measured as the output/employment ratio.

Productivity growth is often credited to "technological progress" due to reorganization of production, more efficient capital goods, or better use of capital. In practice it may arise from greater labor exploitation or sharper competitive practices on the part of business. Regardless of the forces it reflects, productivity plays a dual accounting role for economic growth because it affects both employment and distribution. 
We begin with the evidence and then proceed to interpretation. Our aim is to shed light on matters that usually stay murky when the focus is on the economy as a whole. The paper traces shifting patterns of output at a "meso" level involving 16 sectors producing goods and services. In particular, we analyze how strongly income inequality is driven by pressures on wages as opposed to "monopoly" gains in industries such as manufacturing, information, finance and insurance, and real estate.

Value-added is the standard metric for output. The numbers come from the Bureau of Economic Analysis (BEA), beginning in 1987 and are subject to index number complications. Yearly levels of "real" value-added are estimated by "double deflation.” A sector's gross output including intermediate inputs is deflated by an "appropriate" price index. The value of the intermediates deflated by another index is then subtracted to generate real value-added. Yearly estimates are strung together using a "chain index" (with varying weights over time) to produce a time series. ${ }^{1}$

\section{Figure 1 here}

Figures 1 shows sectoral shares of output in their total. Panels A and B show that five sectors - real estate rental and leasing (RE), business services, manufacturing, education and health, and finance and insurance (FI) - generate $60 \%$ of output. Their shares are fairly stable, with an increase in business services (a mixed bag of enterprises ranging from call centers through collection agencies to credit bureaus, etc.) and a decrease in education and health. In

\footnotetext{
${ }^{1}$ The BEA paper by Moyer, et. al. (2004) provides a helpful methodological summary. In a bit more detail, a sector's total cost can be broken down into costs of intermediate inputs and value-added. Double deflation treats real value-added as a residual and so focuses on the inter-industry structure of production. Current price estimates discussed below tend to estimate levels of output and value-added directly, making intermediate costs the residuals.
} 
panel B, the share of the information sector increases by two percentage points. Information (a combination of traditional publishing, movies, data processing, etc.) together with wholesale and retail trade produce another $15 \%$ of output. Construction and utilities stagnate in panels C and D respectively.

Interrupted by the 2008 recession, the share of finance and insurance goes up by almost two points while real estate falls and rises in the range of $15 \%$. The two sectors are often lumped into a FIRE composite, although as will be seen they differ in several respects.

In terms of chain-indexed output levels, the share of manufacturing drops by about one percentage point. In current price terms (not shown) its share goes down from $22 \%$ to $14 \%$ while other sectoral shares remain fairly stable (with mining fluctuating a few percentage points because of price changes). The difference for manufacturing arises because current price numbers ignore double deflation, estimating levels of output and components of value-added directly, while more or less treating the values of intermediate inputs as residuals.

Because it more closely reflects the structure of production, we opt for chain-indexed double deflated value-added here. Figure 2 presents the sectoral levels of productivity the procedure generates since $1990 .^{2}$

\section{Figure 2 here}

Panel A shows very high productivity sectors, with value-added per employee ranging close to a million dollars in real estate. All four sectors have strong monopolistic elements ("natural" as in utilities and mining, or otherwise). Productivity roughly doubled over 26 years in the information sector and rose by around $50 \%$ in real estate.

\footnotetext{
${ }^{2}$ Data on employment, the denominator used in computing productivity, come from the Bureau of Labor Statistics (BLS) in series beginning in 1990.
} 
Panel B shows that manufacturing productivity more than doubled, while its output share is four times that of information in Figure 1. Along with productivity trends in other sectors, this comparison suggests why the real output share of manufacturing was stable while its current price share declined sharply. Rising productivity means that prices for manufactured products fell in comparison to prices of goods and services from other sectors. This contrast reflects manufacturing's traditional role as a major source of productivity increases.

The education and health sector in panel $\mathrm{C}$ shows the other side of the coin. In doubledeflated terms (panel A of Figure 1) its output share fell from eleven to ten percent. Yet its market price share (not shown) rose from seven to ten percent - falling productivity led to rising costs to consumers (Frank Lysy, 2015).

Other sectors in panel B, especially wholesale trade, enjoyed productivity growth. The same is not true for sectors with lower outputs per employee in panels C and D - almost all showed stable or declining productivity. The main exception is agriculture, which from Figure 1 accounts for only about one percent of output.

Productivity growth also means that manufacturing does not generate robust employment increases, as shown by its share's drop of almost six points in panel A of Figure 3b. Employment has grown rapidly in education and health, and business services. Construction was hit hard by recession in panel $\mathrm{B}$. The share of agriculture tailed off from two to one percent in panel C.

\section{Figures $3 \mathbf{a}$ and $3 \mathbf{b}$ here}

The growth rate of the employment/population ratio can be expressed as a weighted average of the differences between sectoral growth rates of output per capita and productivity 
growth. The weights are sectoral shares in total employment. ${ }^{3}$ Results from this decomposition appear in Figure 4. The green bars show sectors' contributions to employment growth resulting from output increases; the gold bars represent employment losses due to rising productivity. Immediate observations follow.

\section{Figure 4 here}

Output growth in manufacturing does create jobs, but the gain is more than offset by productivity increases. Among the sectors with larger employment share movements, similar observations apply to FI, information, agriculture, and wholesale and retail trade.

Job growth in education and health is supported by demand and (at least according to BEA and BLS data) falling productivity. Rising productivity in business services reduced employment but the impact was more than offset by increasing output.

Development economics emphasizes that as income rises production shifts away from agriculture through manufacturing to "tertiary" sectors (Ocampo, Rada, and Taylor, 2009). The US economy has continued this pattern for the last three decades, with the added complication of a large education and health sector with negative productivity growth. Productivity also fell in construction and other services.

Most of the 16 sectors considered here are (to a greater or lesser extent) "non-traded." The main exceptions are manufacturing, FI, information, mining, and agriculture. As has been widely discussed, import competition and outsourcing have no doubt destroyed jobs in traded goods while contributing to onshore productivity. There is less foreign competition in wholesale and retail trade. As shown in Figure 2 better inventory management and information processing

\footnotetext{
${ }^{3}$ Another chain-index with time-varying weights is involved. The algebra is in the appendix.
} 
pushed up productivity and generated low wage employment (think McDonald's, Walmart, and Amazon).

Robots (or to use an older label, automation) have no doubt eliminated jobs, in a process that dates back at least to the introduction of power looms in England more than two centuries ago. Immigration had lesser effects. Foreign-born workers make up 17\% of total employment, $29 \%$ in construction, and $42 \%$ in agriculture, all with weak upward trends.

\section{Productivity, wages, and profits}

The "real" output and employment indicators just discussed can be combined with distributional data to say something about profits. The BEA provides current price information about the distribution between labor payments and profits at the sectoral level. Treating "valueadded" as the sum of these flows one can compute wage and profit shares which sum to one.

In turn, the wage share equals the ratio of an index of the real "product wage" (or the cost of labor to the firm) to productivity as calculated above. ${ }^{4}$ Another concept is the "consumption wage," measured in terms of a consumer price index. It is not the main focus here, but is affected by productivity trends as discussed above with regard to education and health.

As we have seen, tension between productivity and demand growth determines employment growth. Similarly, differences in growth rates of productivity and real product wages set profits. Expanding on a decomposition proposed by Moshe Syrquin (1986) one can show that the growth rate of the overall profit share can be expressed as a weighted average of each sector's productivity growth minus real wage growth plus a "reallocation" term for the

\footnotetext{
${ }^{4}$ We estimated a sector's product wage as the product of its labor share and productivity. The series are close to independent estimates of real wages. To give an example in round numbers, in panel B of Figure 6 below, the end-of-period profit share in manufacturing is around 0.53, implying a wage share of 0.47 . Productivity is $\$ 150$ thousand, giving a wage of $\$ 70$ thousand.
} 
growth rate of the its share of output. The weights are ratios of sectoral wage payments to total profits. One implication as we will see below is that a sector with a low wage share is not going to make a big contribution to overall profit growth (again consult the appendix).

To lead into the decomposition, consider ratios of sectoral profits to value-added, displayed in Figure 5. Four observations stand out.

\section{Figure 5 here}

The first is that there was an upward trend of the ratio of total profits to value-added (as here defined). What were its causes?

Second, in terms of levels, in panel A real estate profits account for one quarter of the total, with an upward trend. Back in panel A of Figure 1, RE has a large and stable (postrecession) share of output. In panel A of Figure 6, its own-profit share is extremely high. As will be seen, however, the Real Estate (RE) sector does not contribute significantly to overall profit growth. If RE business already has profit share close to one, then its contribution to total profits cannot go up by very much.

\section{Figure 6 here}

Third, other sectors with high levels of profits are manufacturing, business services, finance and insurance, and information.

\footnotetext{
${ }^{5}$ Somewhat confusingly, besides the RE sector the national product accounts also include "rental income of persons" in household consumption. It is a fiction which national accountants chose to introduce long ago and has nothing to do with the real estate sector in the conventional sense. Double-entry bookkeeping dictates that this consumption also has to be counted as a (fictional) component of household income. The actual number is based on observed rents which are used to estimate the "imputed" income generated by "owner-occupied housing." Panel A of Figure 4 shows that this fabricated flow is not small, and that it tracks RE profits.
} 
Fourth, in Figure 6 own-profit shares in mining, information, manufacturing, wholesale and retail trade, and construction show increases; entertainment, food and lodging, and business and other services drop off.

Figure 7 summarizes how these trends have gone together since around 1990. The red bars capture the effects of changes in sectors' shares of output on the overall profit share, yellow represents effects of wage increases, and green does the same for productivity growth. Share changes net out at the bottom which shows what happened to the overall profits - productivity outran real wages.

\section{Figure 7 here}

Effects of demand shifts were relatively minor, but they did stimulate profits in information, wholesale and retail trade, and FI. Along with manufacturing, these sectors played the major roles in driving profits economy-wide. Among minor contributions, construction suffered from a demand shift and falling productivity but benefitted from reductions in real wages.

Business services, a large sector with a slowly growing output/employment ratio, had relatively strong wage increases. It may exemplify the "Baumol disease" (Baumol and Bowen, 1966) via which pressure for wage equalization across sectors means that profits get squeezed in the ones with lagging productivity. Mining and education and health may be in the same boat, but the disease does not appear to strike economy-wide. Productivity growth plus demand shifts outran wage growth in information, FI, and wholesale and retail trade.

\section{Explanations}


There are several lines of thought about forces generating slowly growing employment and a rising aggregate profit share over the past four decades. Three are wage repression, greater business market power which increases "rents" accruing to owners of capital, and finally the traditional rental payments received by owners of real estate. We can quickly sketch the reasoning, and compare to Figures 4 and 7. Each explanation has some traction, but they are not equally important.

Wage repression involves interventions to hold down wages against prices of goods and services. At the macroeconomic level, a key policy is austerity which suppresses employment and so reduces the ability of labor to push for higher pay. Individual firms may exert "monopsony" power to constrain wages in markets in which they "buy" labor. The instruments are institutional.

Besides the effects of austerity, at the governmental level they include long-term stalemate at the National Labor Relations Board and the spread of state-level right-to-work laws, handicapping both unionization and unions' bargaining power.

Stagnant minimum wages at the bottom of the size distribution of income are only recently beginning to increase but at the same time non-poaching and non-competition clauses in contracts (which restrict job opportunities outside a company for a worker who leaves it) have been spreading rapidly. Divide-and-rule employment tactics in a "fissuring" labor market as described by David Weil (2014) are another aspect of this process.

Globalization and outsourcing have held down wages as well as employment. In construction and agriculture, immigration may well have repressed wages, but these sectors make a modest contribution to output. Maybe the recent increase in the employment ratio (Figure 3a) will enhance labor's bargaining power, but it is still below the peak in 1990 . 
Perhaps because they don't want to think about class conflict, mainstream economists mostly opt for explanations based on business "monopoly" power to drive up prices against wages. Recipients of high incomes such as corporate CEOs supposedly benefit from rents generated by monopoly (Stiglitz, 2016).

In one example at the micro level, an expanding presence of "superstar" firms with high productivity may drive down the average sectoral wage share (Autor, et. al., 2017). ${ }^{6}$ The question then becomes what are the institutional barriers that prevent workers in these firms from getting higher pay? We get back to wage repression as an explanation.

Assuming that such barriers exist then increasing concentration of firms in a sector should be associated with a higher profit share with stable or falling employment. In Figure 7, of the half-dozen sectors (reading up from the bottom of the diagram) that have had the biggest impacts on growth of profits, the common perception is that there has been growing enterprise concentration in information and FI. Their employment generation in Figure 4 has been weak.

Wholesale and retail trade may well have relied on wage repression, with somewhat slower demand than productivity growth. Manufacturing is perhaps a mixed bag with regard to profits, while shedding jobs. But its large employment losses suggest that superstar firms that can raise production and profits while maintaining employed workforces must not be common.

Construction's performance has been poor in general. Weak productivity increases in the face of growing demand have supported employment increases in business services and education and health.

\footnotetext{
${ }^{6}$ The idea is reminiscent of the "Horndal effect" of rising productivity in a Swedish steel mill over decades during which time there was no significant investment in new capital. Learning by doing is the standard rationalization (or label).
} 
In macroeconomics, a persisting differential between the corporate profit rate and the (real) interest rate can create a surplus siphoned to shareholders via capital gains (Eggertsson, et. al.,2018). The paper can be viewed as a rationale for Piketty's (2014) emphasis on asset price increases as sources of rising wealth.

The story is set out in orthodox new Keynesian garb. It fits the data, beginning with the "put" on interest rates that the Federal Reserves instituted around 1990, but is less convincing over a longer period of time. The label comes from the jargon of financial derivatives. A put option is a contract which allows its owner to sell an underlying security at a specified "strike" price when the market price goes below that level, thereby cutting losses. Beginning during Alan Greenspan's tenure as Governor, the Fed would typically reduce the Fed funds rate when the stock market fell by more than $20 \%$, creating money to buy bonds and support private capital gains. ${ }^{7}$ Ongoing financial deregulation was another part of the put. So was a general recognition that the government would step in to prevent financial collapses, as happened in 2008.

Are such interventions feasible in the long run? There is no reason to assume that the put and its associated wedge between profit and interest rates will persist (just recall the Fed's interest rate hikes around 1980 and 1994, which caused market chaos). As shown in Figure 8, Tobin's $q$ or the ratio of stock market valuation to the replacement value of capital, fluctuates over the decades, with some tendency toward "reversion to mean." Unsurprisingly the ratio started to rise in tandem with the Fed's put. When interest rates inevitably go up, $q$ can be expected to decline.

Figure 8 here

\footnotetext{
${ }^{7}$ That is, relative to a stock market index of 100 , the Fed's strike price was 80 .
} 
In any case rate differentials are irrelevant to the gap between wage and productivity growth rates shown in Figure 7. One might add that the new Keynesian idea that the "natural" or "neutral" interest rate has shifted downward permanently makes no institutional sense. The natural rate concept dates to the turn of the Twentieth Century. It may have described transactions between households and business with the economy at full employment back then, but was repudiated in the 1930s by John Maynard Keynes and is inconsistent with the contemporary roles of business, government, and the rest of the world in the saving-investment process (Taylor, 2016).

These narratives invoke hard-to-quantify, somewhat metaphysical rents created by market power. We should also consider rents as the visible payments by tenants to owners of real estate. Since the time of David Ricardo two centuries ago, economists have recognized that rents on tangible property are created by demand derived from other income flows. ${ }^{8}$ Figure 5 shows that profits from real estate rental and leasing make up a large and slowly rising share of the total - in other words demand for real estate services is mildly income-elastic. On the other hand, the sector neither creates new jobs (Figure 4) nor contributes strongly to profit expansion (Figure 7). It is a big source of inequality (think New York or Bay Area real estate!). But at the national level, its significance is not growing strongly over time.

\section{Summary}

Meso level analysis cannot provide microeconomic detail, but it can shed light on broad forces shaping the economy. One vantage point is provided by Figure 9 showing averages over

\footnotetext{
${ }^{8}$ Perhaps, one might add, with positive feedback from higher rental income to rising demand for real estate. Such an effect is likely to be weak.
} 
time of the weights used in the chained indexes for the employment and profit rate decompositions. Clearly, sectors with higher wage and employment shares have larger weights.

\section{Figure 9 here}

The diagrams suggest that wage repression likely pushed up profits in business services, education and health, wholesale and retail trade, and parts of manufacturing. Productivity growth cut into employment in these sectors as well as in construction and accommodation and food.

The biggest observed employment losses (Figure 4) have been in manufacturing and wholesale trade; gains were strong in business services and education and health. Profit growth (Figure 7) was robust in manufacturing, trade, FI, and information. The latter two (and wholesale trade) benefitted from favorable demand shifts. They may harbor superstar firms and other exemplars of growing monopoly power which can increase profits and measured productivity. However, they generate less than a quarter of total profits. Owners of real estate receive more than a quarter but their share is not increasing. Growth of the remaining one-half of profits has been due to demand shifts and productivity growth which exceeded real wage increases.

Power matters in all sectors. Its strongest effects act against employment and real wages in labor markets. 


\section{Appendix}

To sort things out a bit more, it helps to look at accounting:

Profits + Wages $=$ Value-added $($ at factor cost $)$

or

Profit share + Wage share $=1$

We work with total and sectoral current price profit shares ( $\pi$ and $\pi_{i}$ respectively) with $\psi$ and $\psi_{i}$ as labor shares. Productivity levels are $\xi=X / L$ and $\xi_{i}=X_{i} / L_{i}$ (with $X=\sum X_{i}$ and $X_{i}$ as chain-indexed output levels and $L$ and $L_{i}$ as employment levels). Real wages are $\omega=\psi \xi$ and $\omega_{i}=\psi_{i} \xi_{i}$ (with $\psi$ and $\psi_{i}$ as current price wage shares). Let $A=\psi / \pi$ and $A_{i}=s_{i} \psi_{i} / \pi$ with $s_{i}=X_{i} / X$. Note that $A_{i}=\psi_{i} X_{i} / \pi X$, or wage payments in sector $i$ divided by total profits. One can show that $\sum A_{i}=(1 / \pi)-1>1$.

In continuous time

$$
\hat{\pi}=A(\hat{\xi}-\widehat{\omega})=\sum A_{i}\left(\hat{\xi}_{i}-\widehat{\omega}_{i}+\hat{s}_{i}\right)
$$

with $\hat{\pi}=(d \pi / d t) / \pi$, etc.

Equation (1) is a Divisia index, with weights that vary over continuous time. We want to find growth rate "contributions" of productivity shifts, wage increases, and share changes when only yearly data are available. One way to do that is to set up a chain index involving discrete time. Using a time subscript, let

$$
\widehat{\Xi}_{i}=(1 / 26) \sum_{t} A_{i t} \hat{\xi}_{i t}
$$

which an average contribution over 26 year of sector $i$ to overall productivity growth. For each period $t$, use the mean of $A_{i t}$ and $A_{i, t+1}$ and let $\hat{\xi}_{i t}=\left(\xi_{i, t+1} / \xi_{i t}\right)-1$.

Similarly, let

$$
\widehat{\Omega}_{i}=-(1 / 26) \sum_{t} A_{i t} \widehat{\omega}_{i t}
$$


and

(4) $\hat{S}_{i}=(1 / 26) \sum_{t} A_{i t} \hat{S}_{i t}$

The growth of the sector $i$ profit share is then approximated by the sum $\widehat{\Xi}_{i}+\widehat{\Omega}_{i}+\hat{S}_{i}$.

Let $\chi_{i}=X_{i} / P$ with $P$ as working age population, $\varepsilon_{i}=L_{i} / L$ with $L$ as total employment, and $\phi=L / P$. Then

(5) $\hat{\phi}=\sum \varepsilon_{i}\left(\hat{\chi}_{i}-\hat{\xi}_{i}\right)$

or employment rises when demand per capita grows faster than productivity.

Sources of data include https://www.bea.gov/industry/gdpbyind_data.htm for valueadded and its components, and https://www.bls.gov/webapps/legacy/cesbtab1.htm and https://fred.stlouisfed.org/series/LNS12034560 for employment. 


\section{References}

Autor, David, David Dorn, Lawrence F. Katz, Christina Patterson, and John Van Reenan (2017), "Superstar Firms and the Falling Labor Share," American Economic Review: Papers and Proceedings, 107 (No. 5): 180-185

Baumol, William, and William Bowen (1966) Performing Arts: The Economic Dilemma, New York: Twentieth Century Fund

Eggertsson, Gauti, Jacob A. Robbins, and Ella Getz Wold, "Kaldor and Piketty’s Facts: The Rise of Monopoly Power in the United States," http://02052018-WP-kaldor-pikettymonopoly-power.pdf

Lysy, Frank (2015) “Why Wages Have Stagnated While GDP Has Grown: The Proximate Factors," https://aneconomicsense.org/2015/02/13/why-wages-have-stagnatedwhile-gdp-has-grown-the-proximate-factors/

Moyer, Brian C., Mark A. Planting, Mahnaz Fahim-Nader, and Sherlene K. S. Lum (2004) "Preview of the Comprehensive Revision of the Annual Industry Accounts, https://www.bea.gov/scb/pdf/2004/03March/0304IndustryAcctsV3.pdf

Ocampo, José Antonio, Codrina Rada, and Lance Taylor (2009), Growth and Policy in Developing Countries: A Structuralist Approach, New York: Columbia University Press

Pasinetti, Luigi L. (1981) Structural Change and Economic Growth, Cambridge UK: Cambridge University Press

Piketty, Thomas (2014) Capital in the Twenty-First Century, Cambridge MA: Belknap Press Stiglitz, Joseph E. (2016) “Inequality and Economic Growth,” in Michael Jacobs and Mariana Mazzucato, Rethinking Capitalism: Economics and Policy for Sustainable and Inclusive Growth, Malden MA: Wiley-Blackwell 
Syrquin, Moshe (1986) "Productivity Growth and Factor Reallocation," in Hollis B. Chenery, Sherman Robinson, and Moshe Syrquin (eds.) Industrialization and Growth, New York: Oxford University Press

Taylor, Lance (2016) “The 'Natural' Interest Rate and Secular Stagnation: Loanable Funds Macro Models Don't Fit Today's Institutions or Data," https://www.ineteconomics.org/uploads/papers/Loanable_Funds_Macro_Models_Taylor _120316.pdf

Taylor, Lance (2017) “Why Stopping Tax "Reform” Won’t Stop Inequality,” https://www.ineteconomics.org/perspectives/blog/why-stopping-tax-reform-wont-stopinequality

Weil, David (2014) The Fissured Workplace, Cambridge MA: Harvard University Press 
Figure 1: Sector Shares of Chain-Indexed Value Added in the total across all sectors.

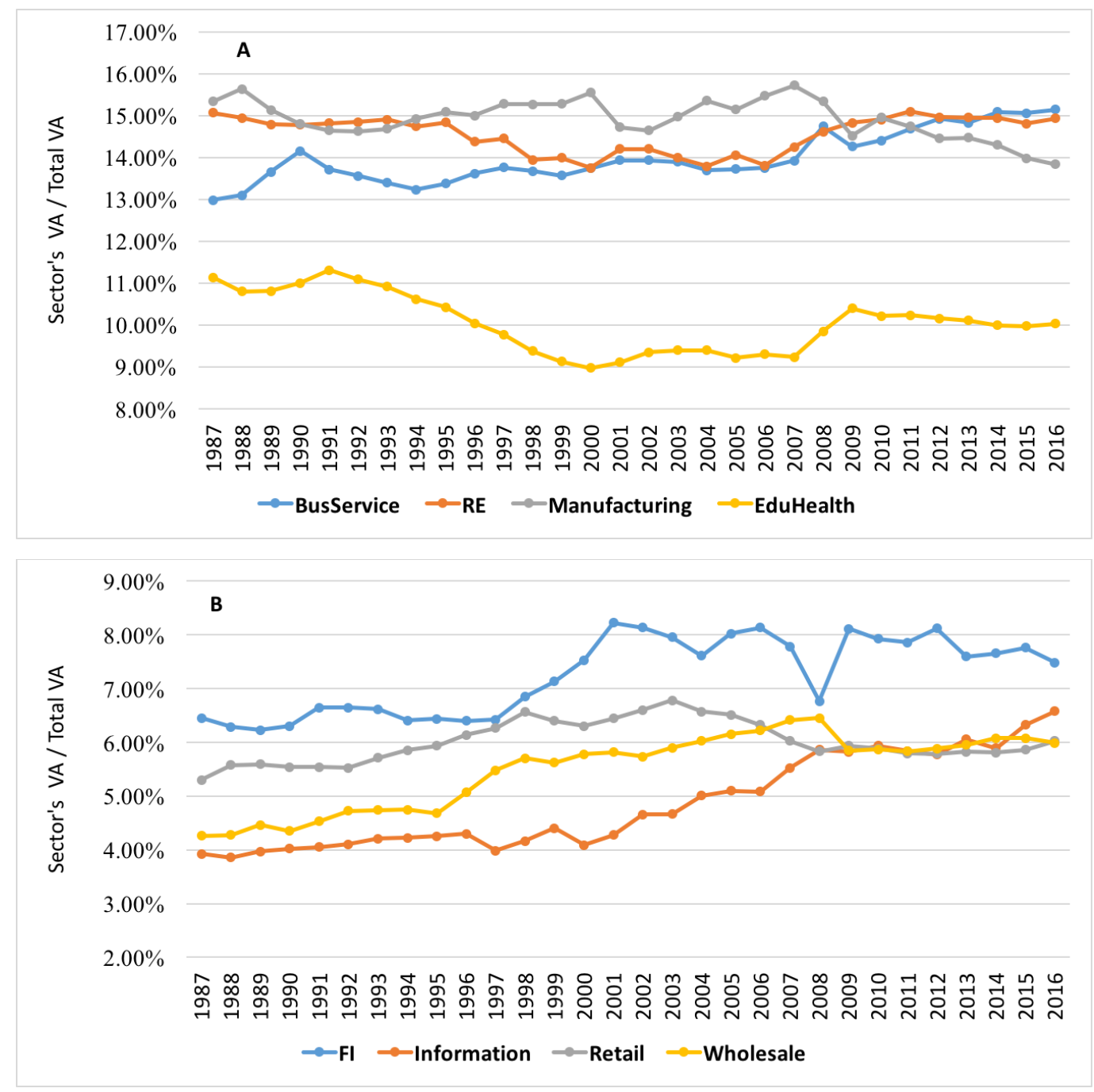



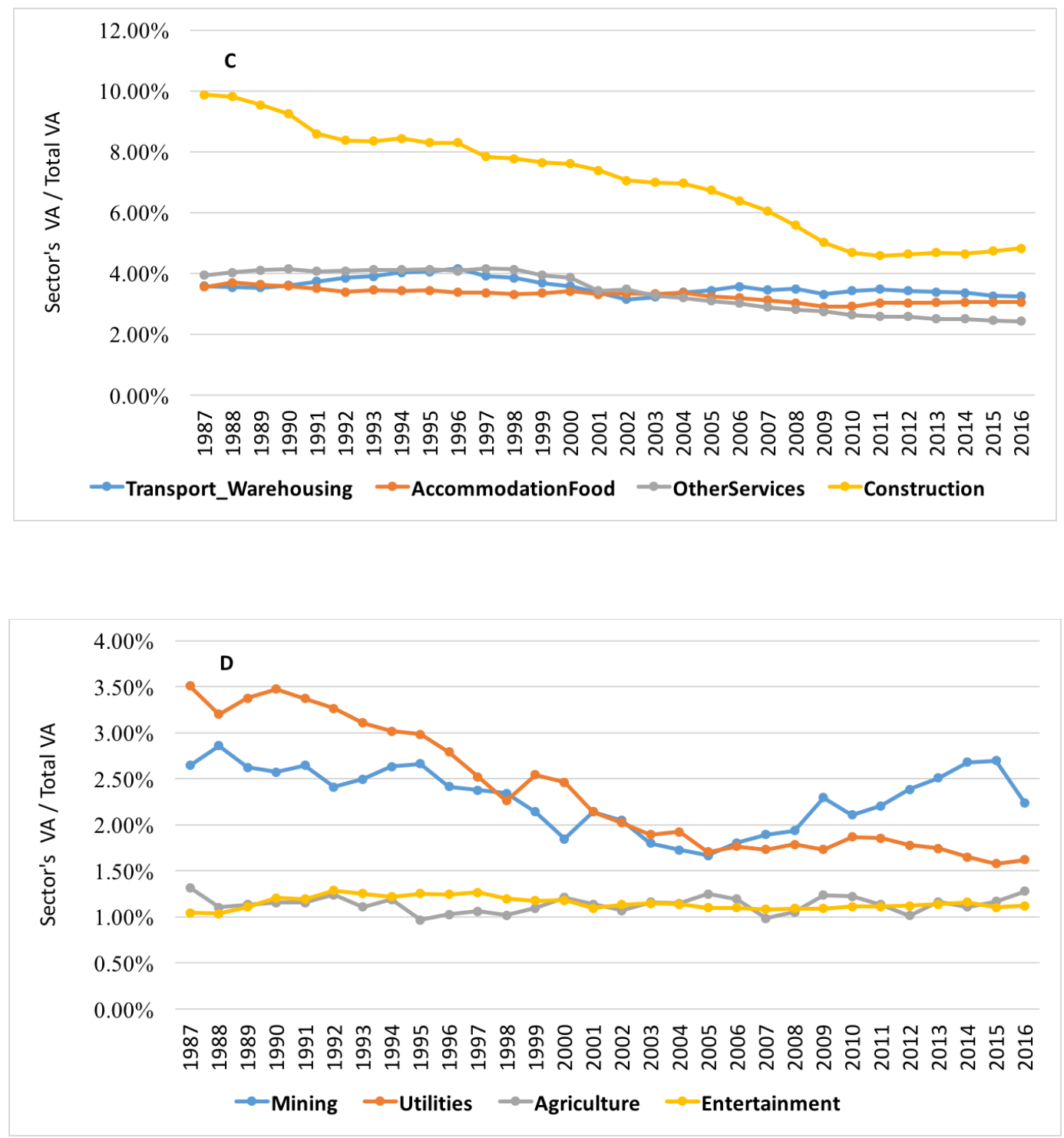
Figure 2: Productivity Levels (Sectoral Real VA / Number of Employees)
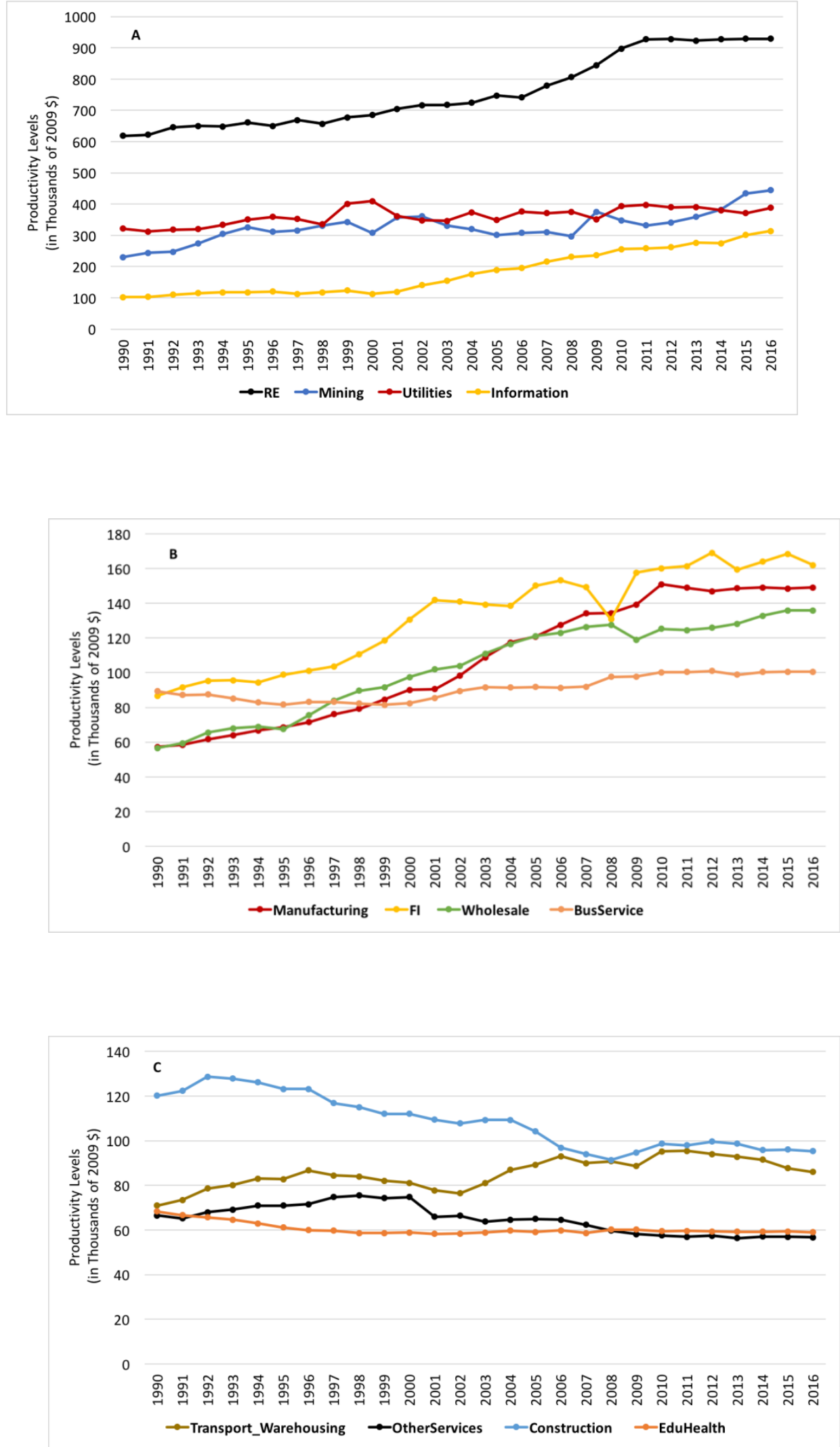


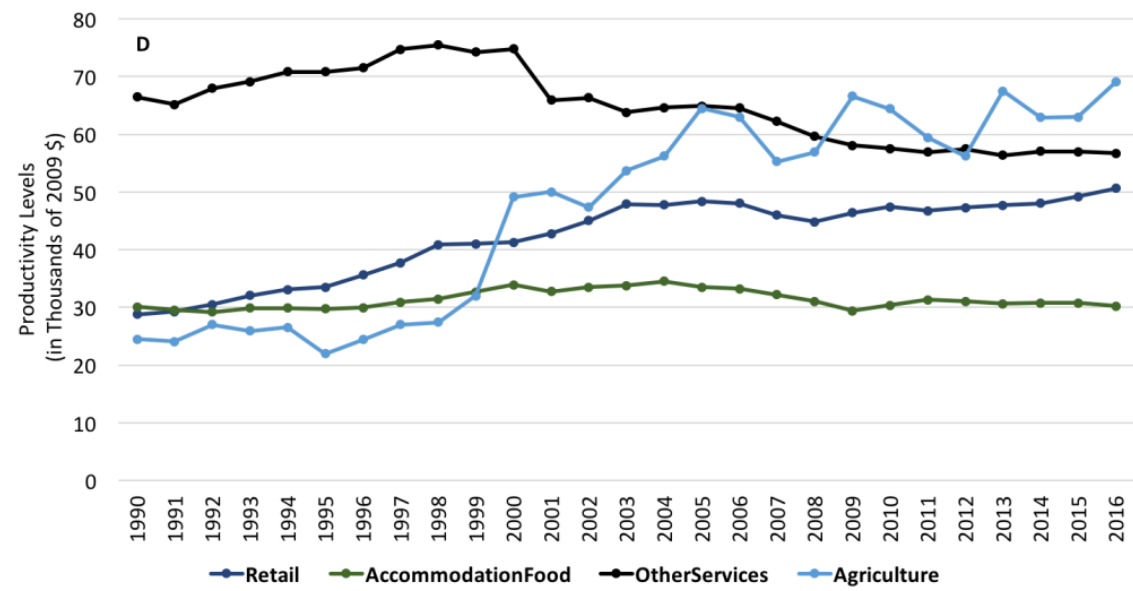


Figure 3a: Private Sector Employment-Working Age Population Ratio

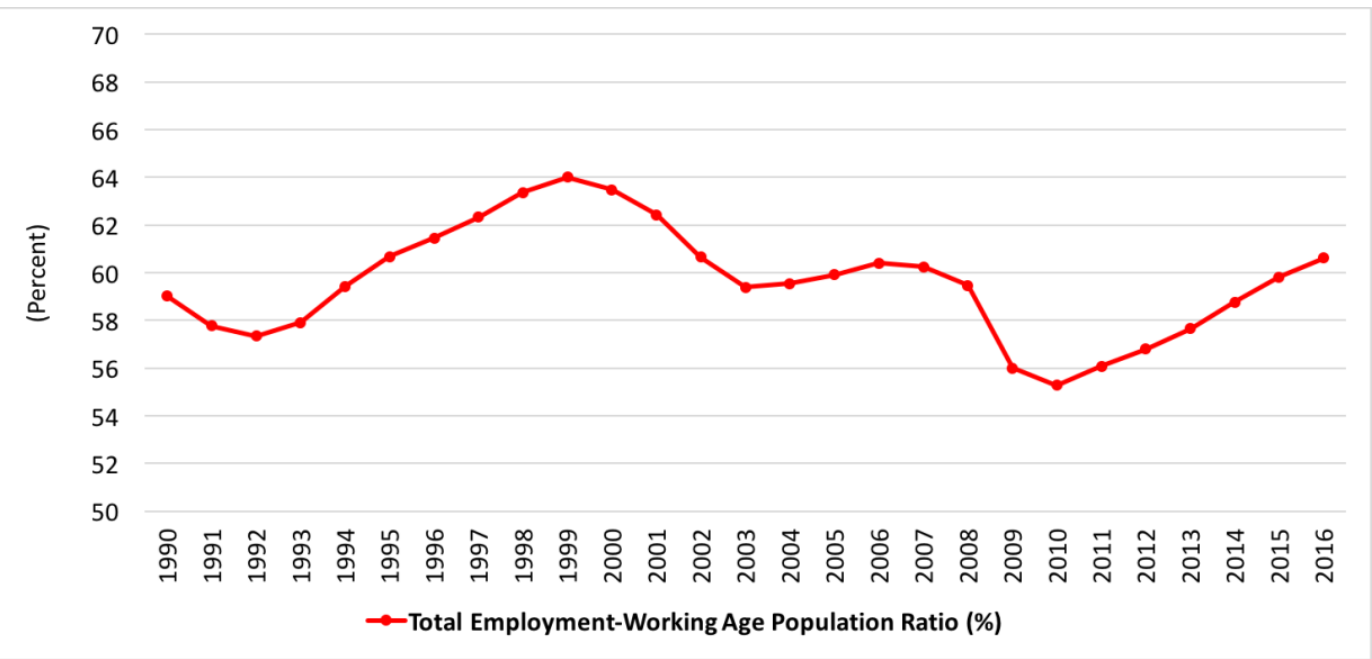

Figure 3b: Employment Shares of Sectors

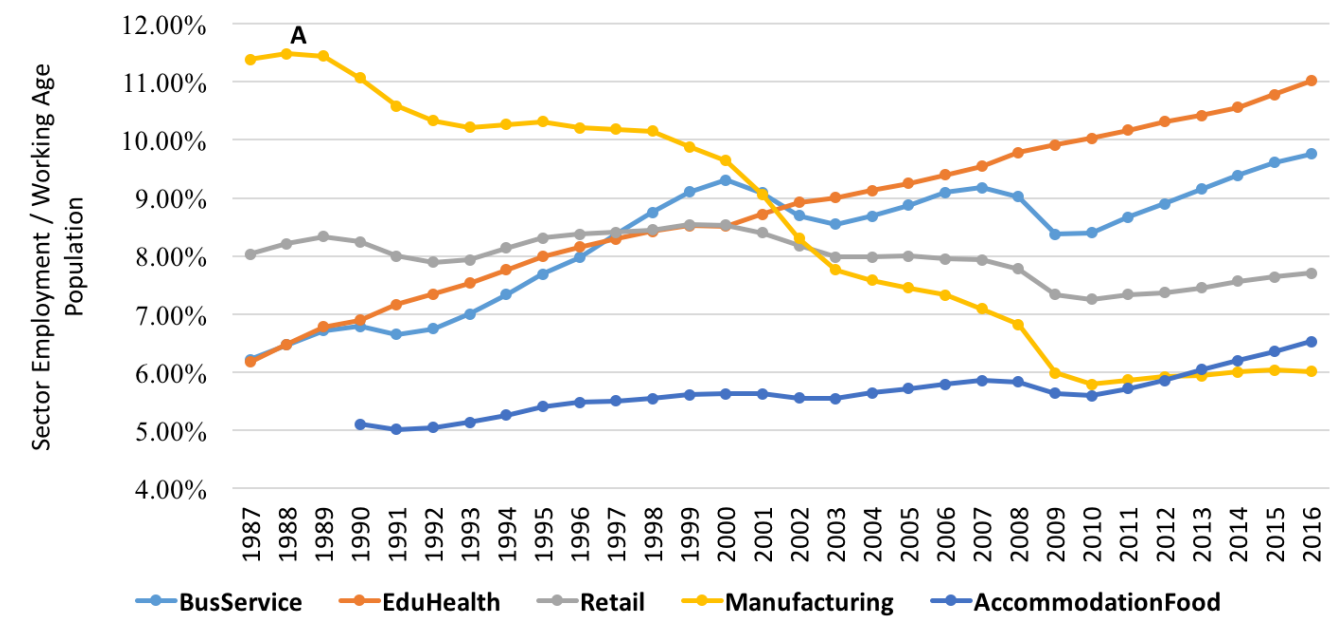



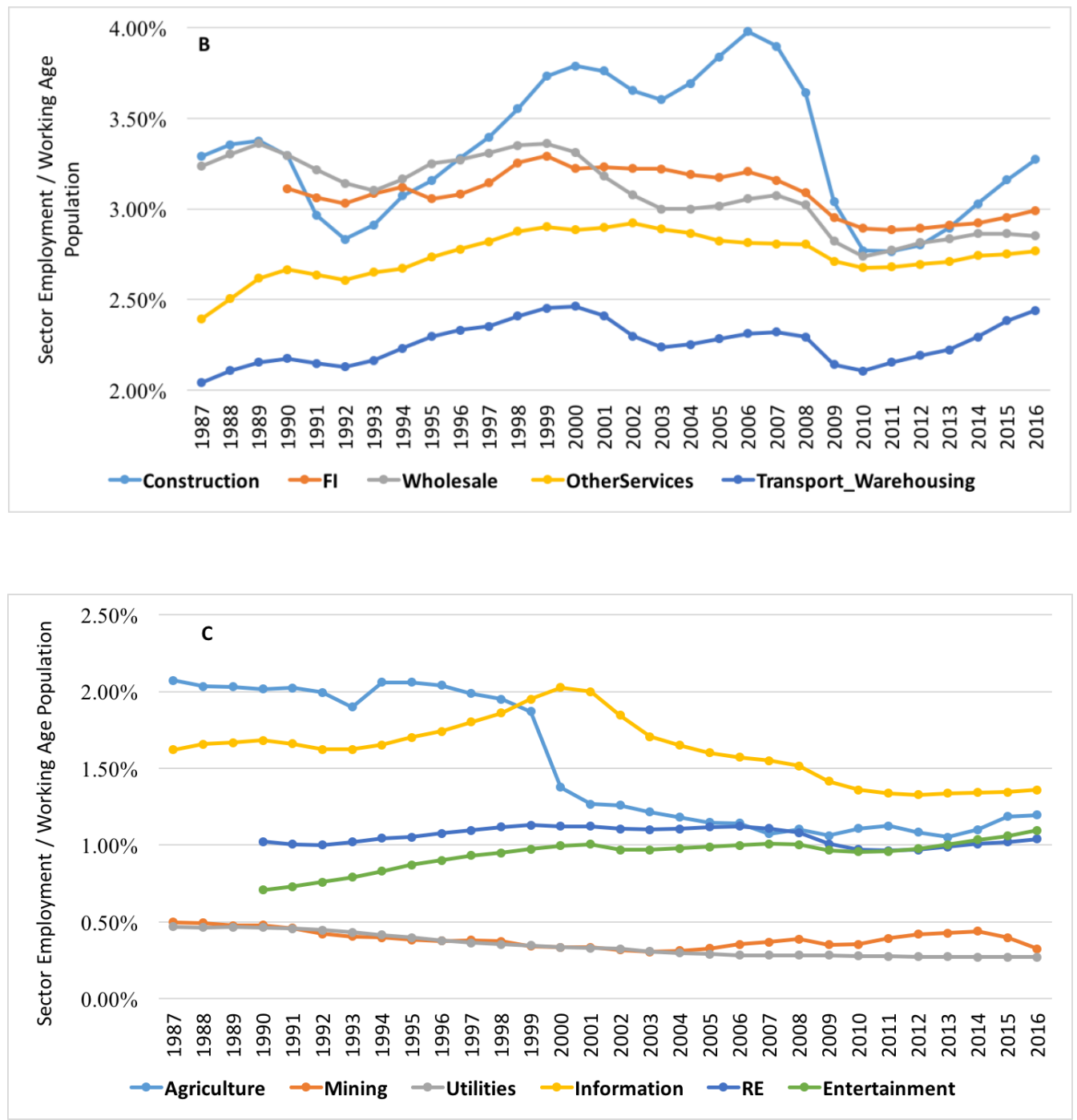
Figure 4: Employment Decomposition

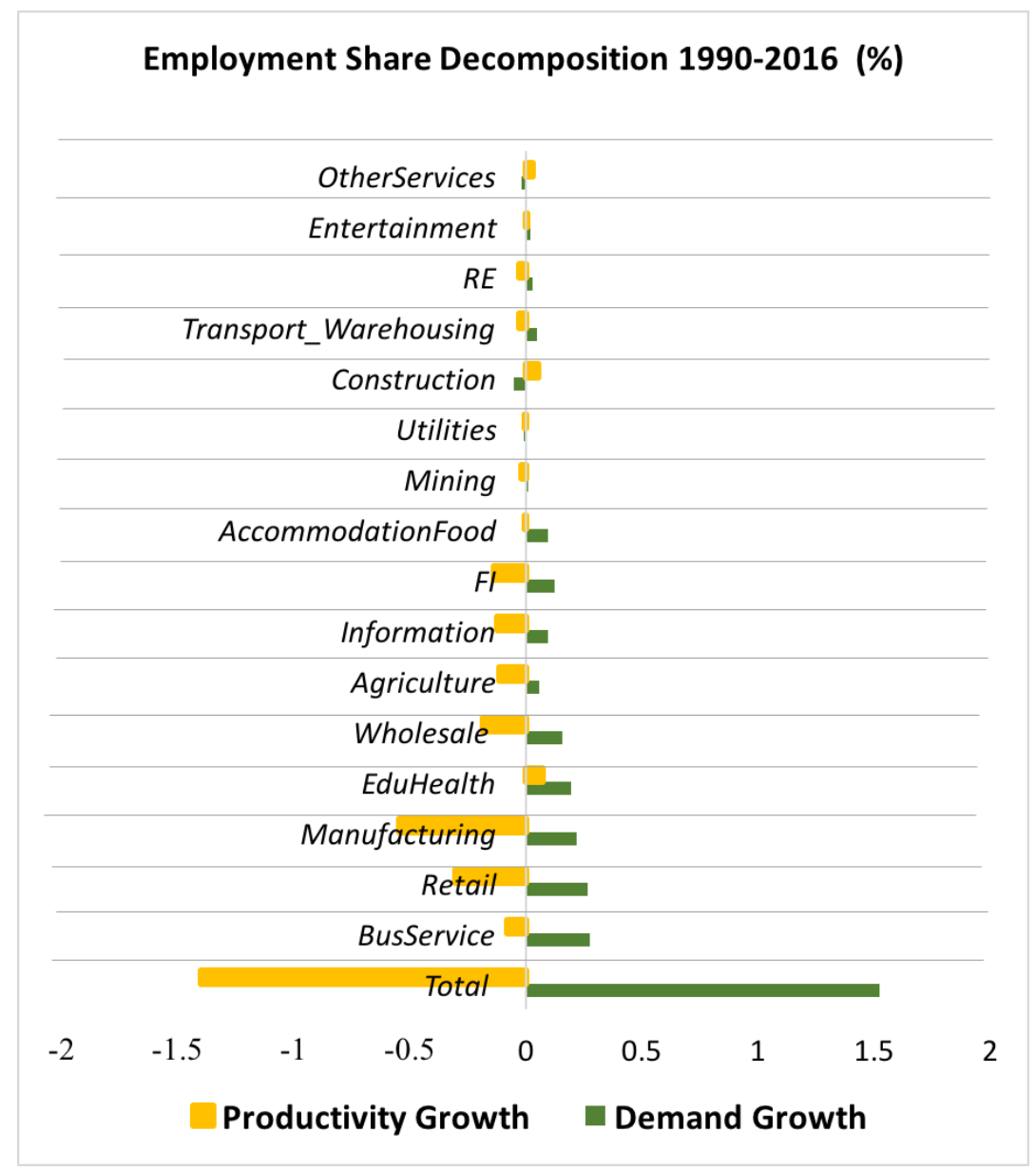

Figure 5: Shares of Current Price Profits in Total Current Price VA

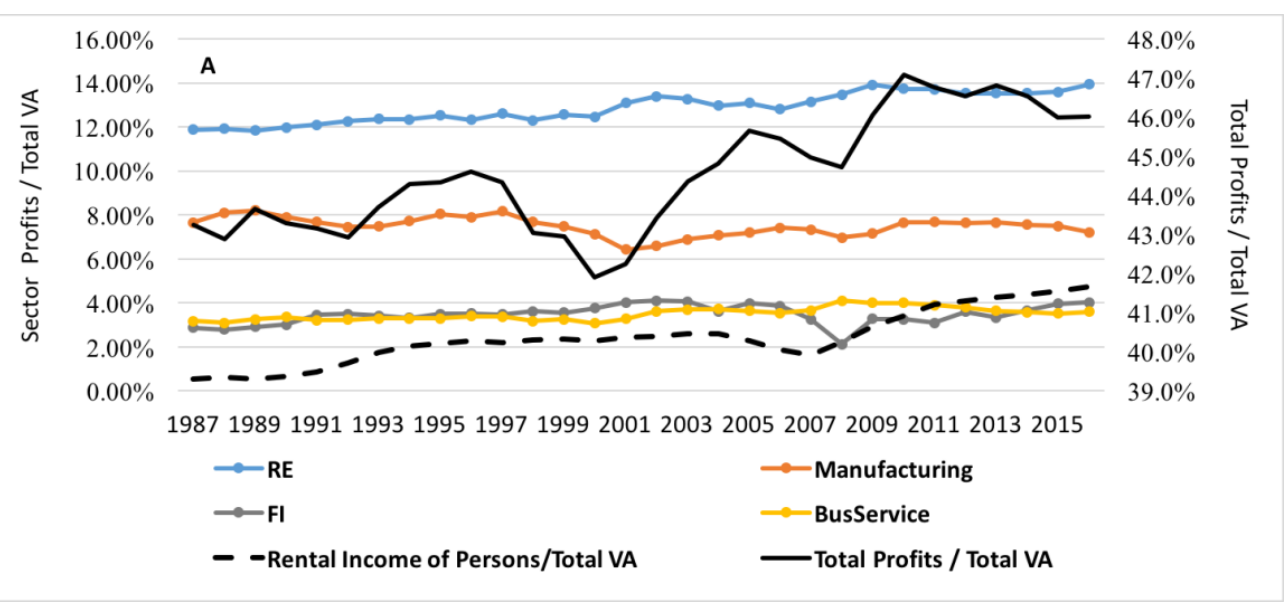



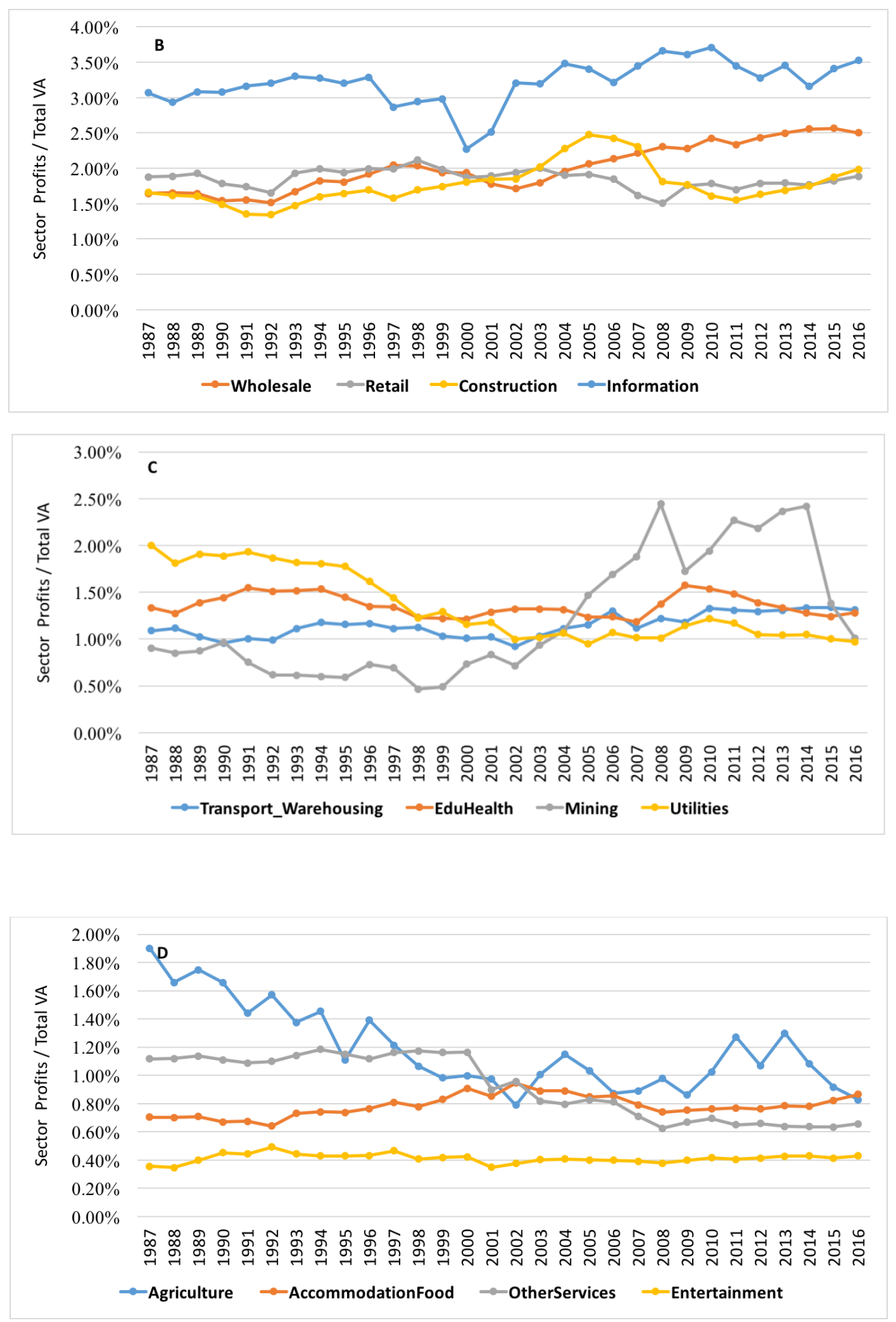
Figure 6: Sectors' Own Profit Shares and Total Private Sector Profit Share

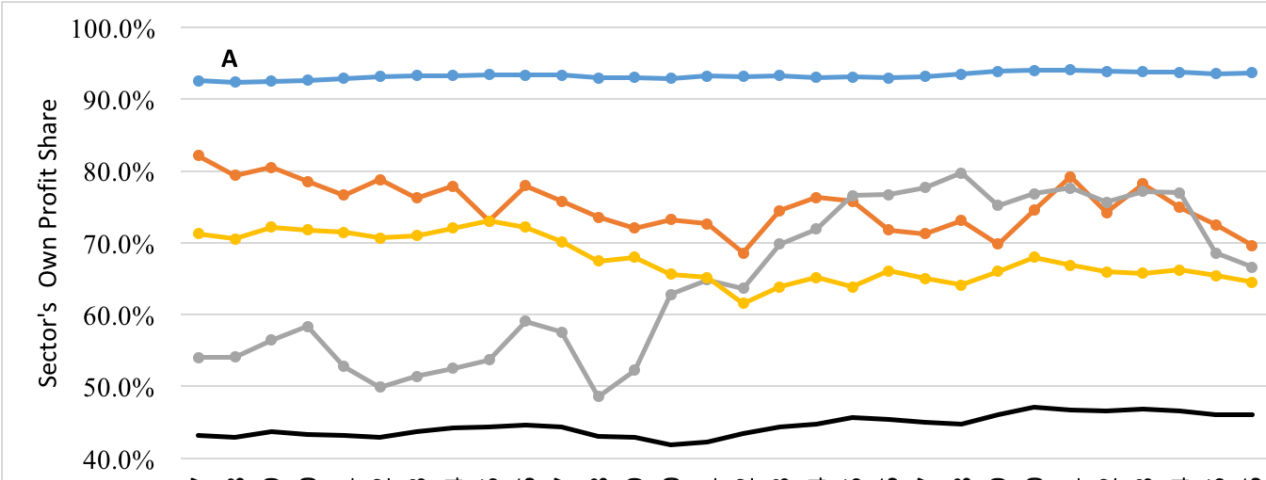

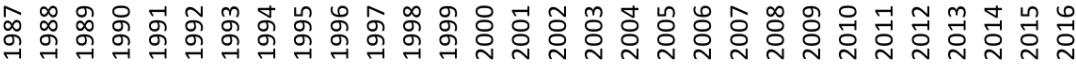
$\rightarrow$ RE $\rightarrow$ Agriculture $\rightarrow$ Mining $\rightarrow$ Utilities $\longrightarrow$ Total Private Sector
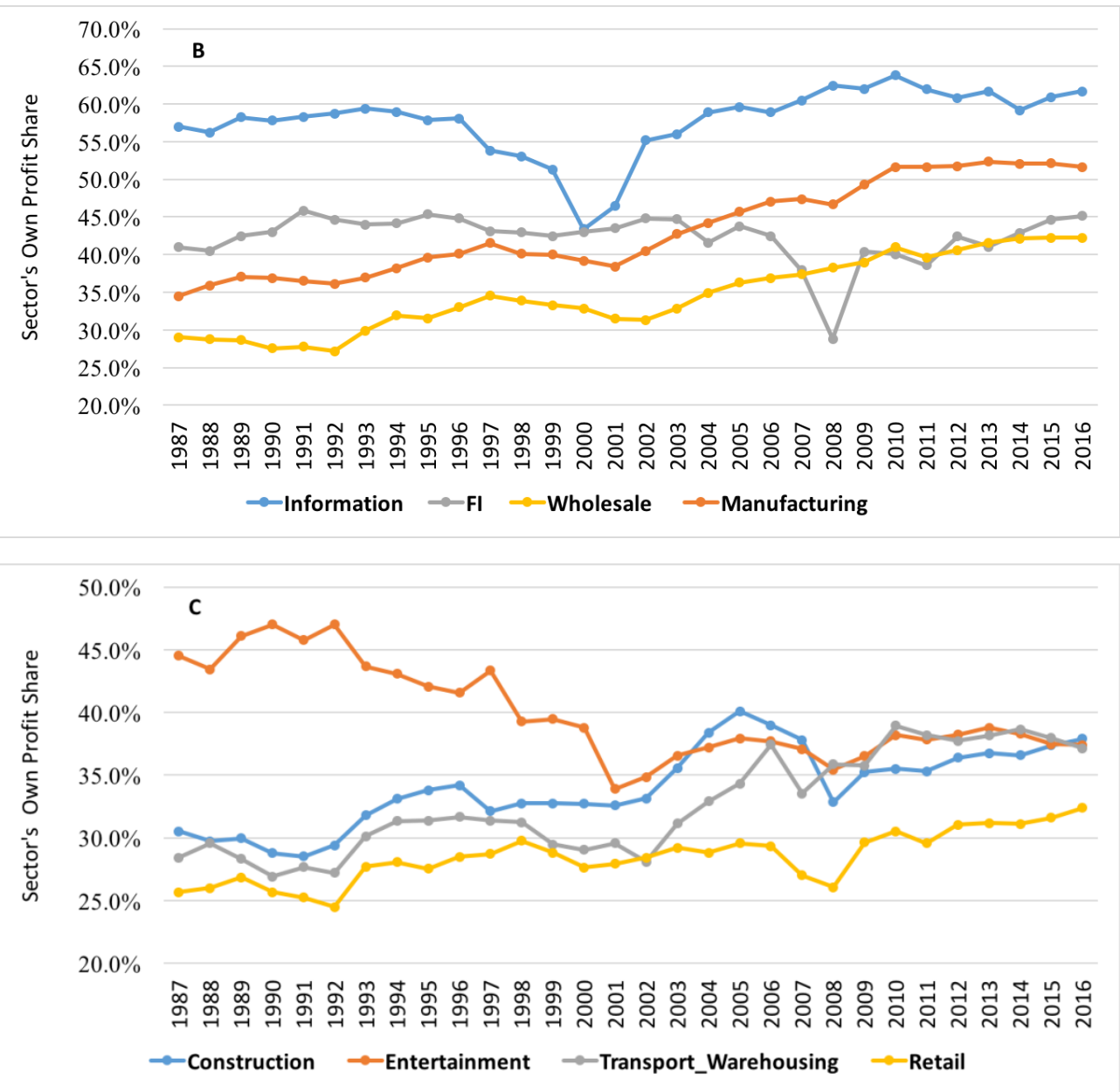


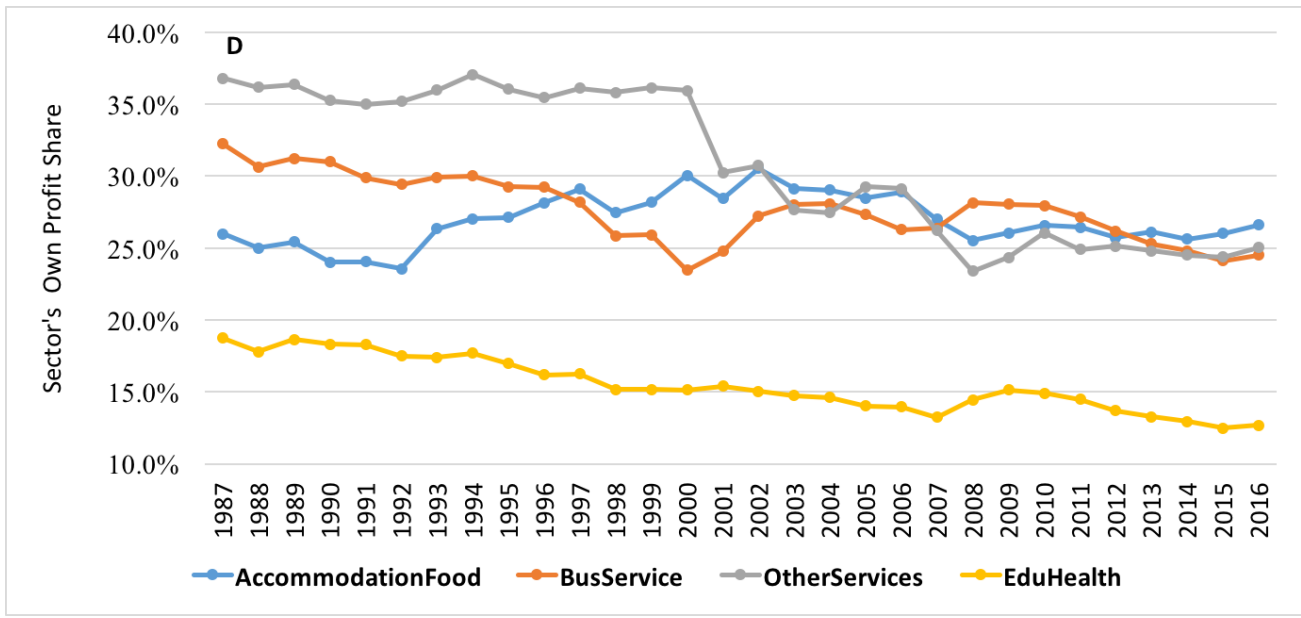

Figure 7: Profit Share Decomposition

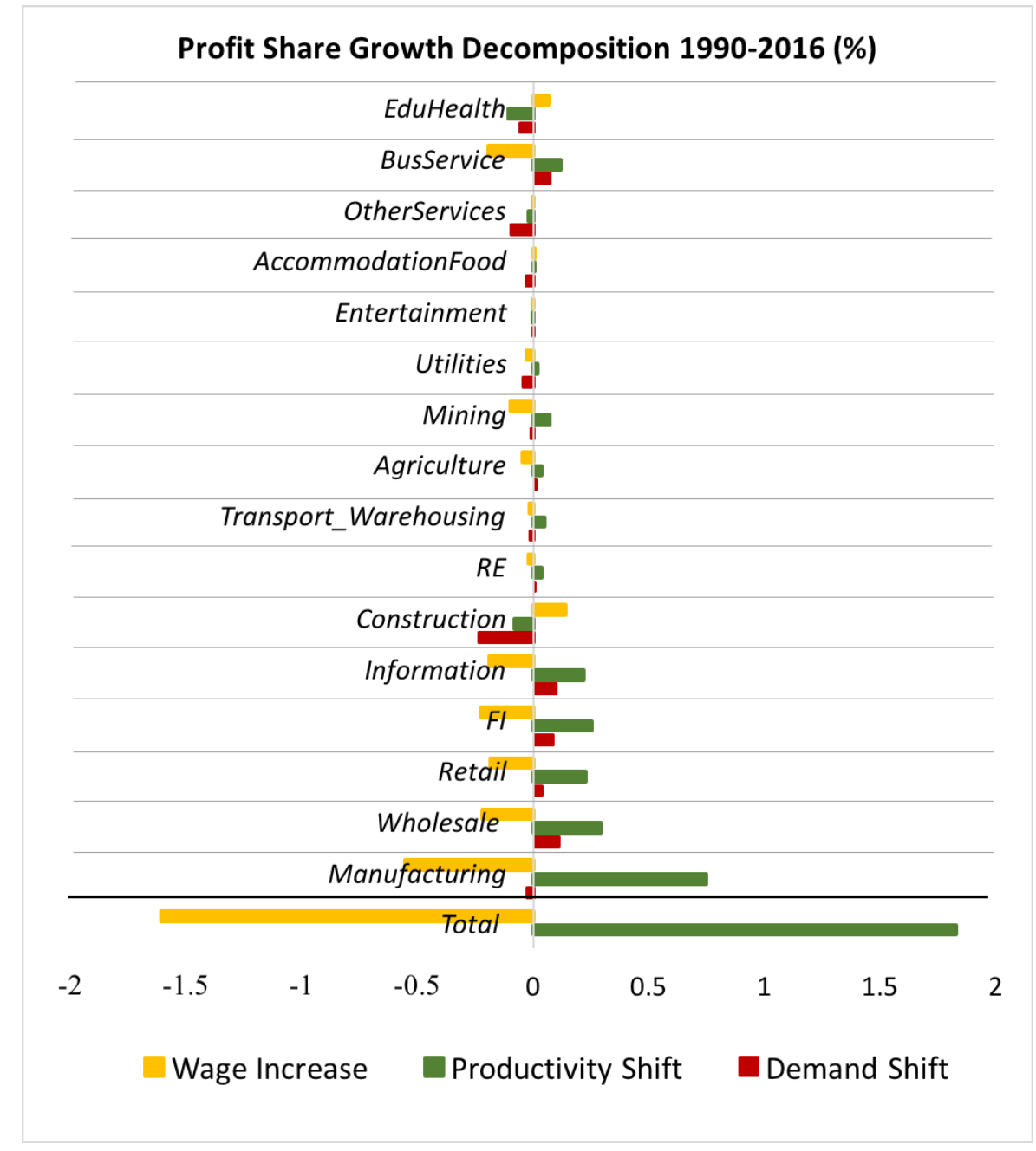


Figure 8: Business sector valuation ratio $q$

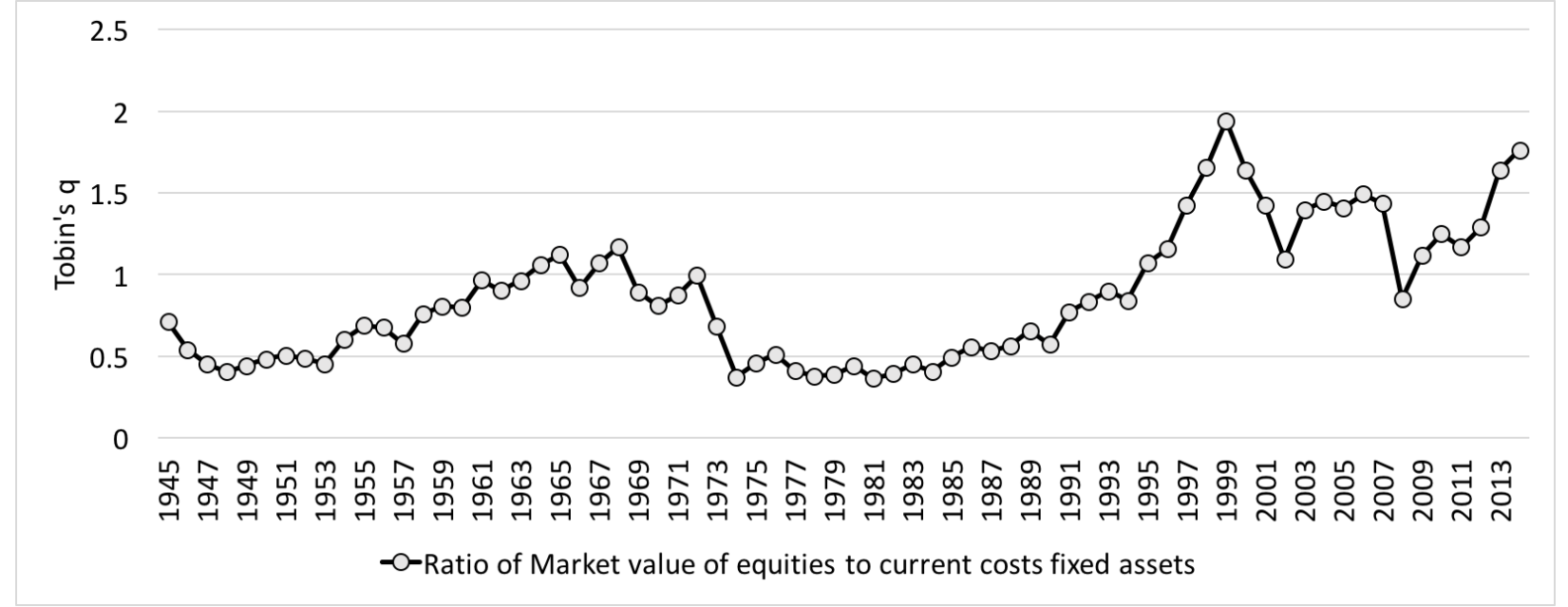

Figure 9: Weights for Decompositions

A. Average $A_{i}$

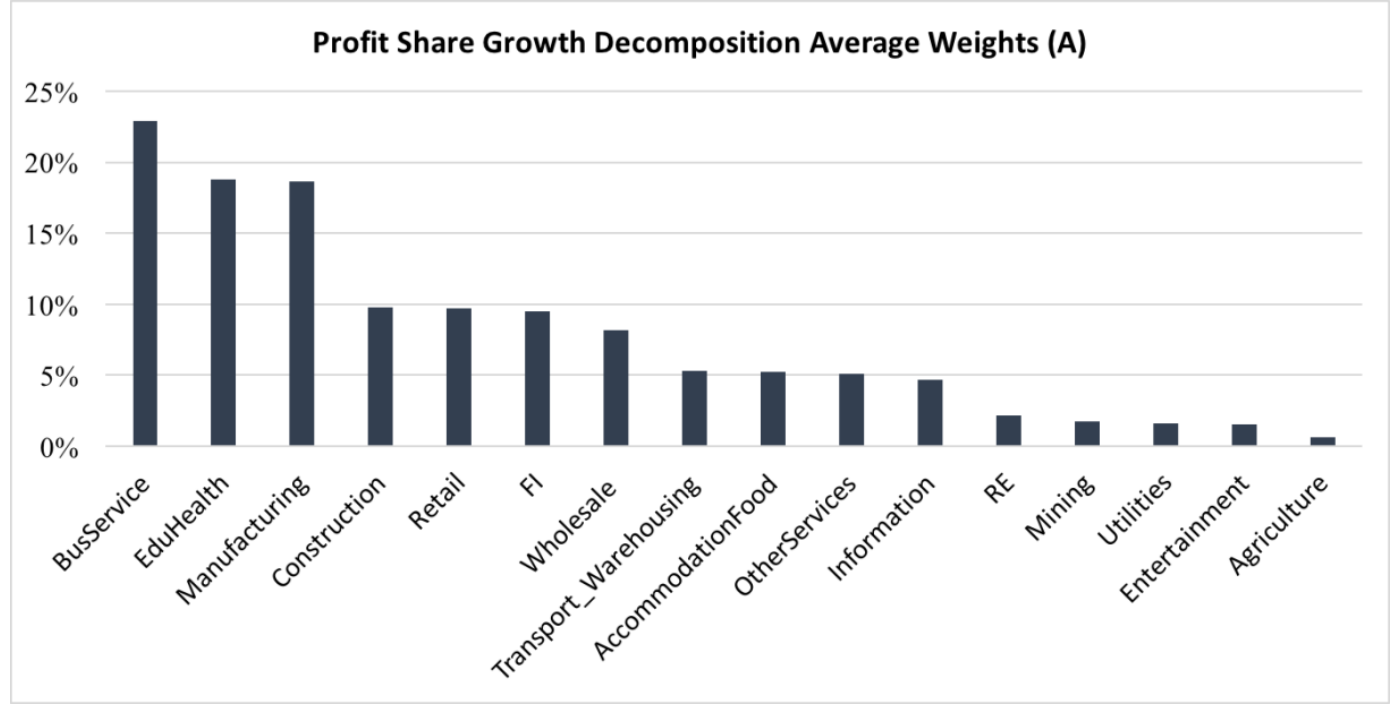




\section{B. Average $\varepsilon_{i}$}

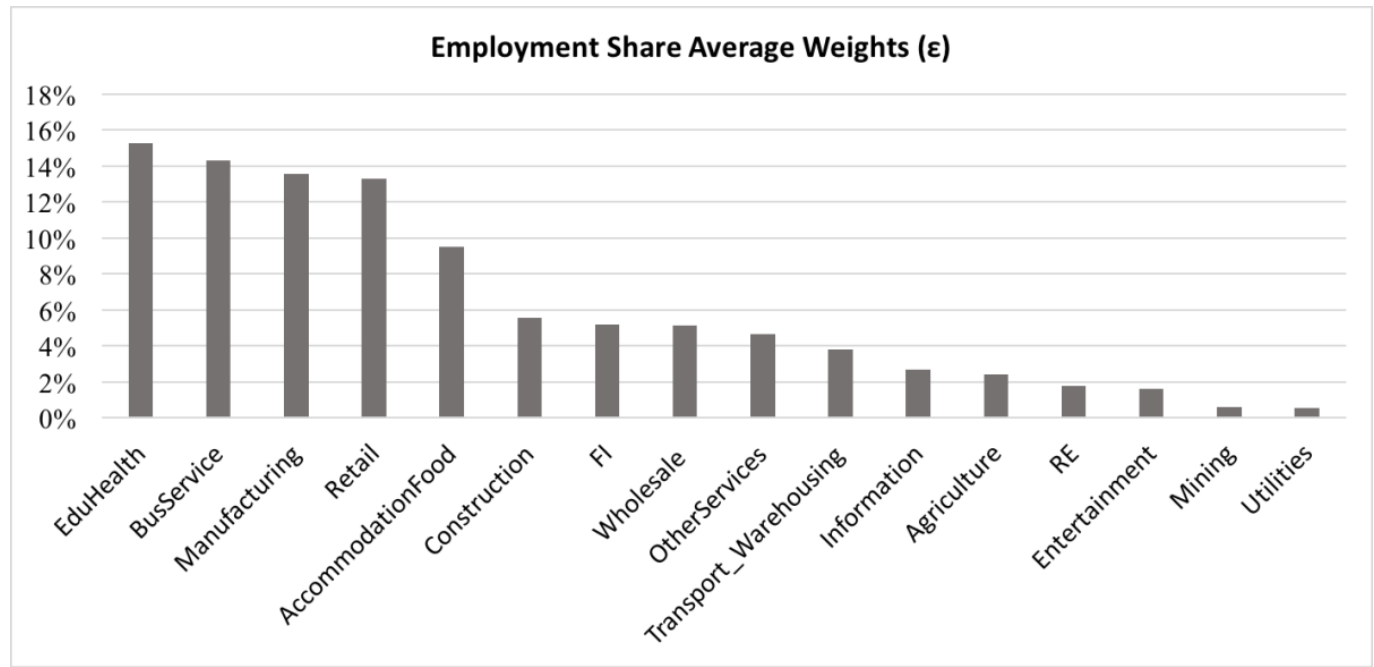

